\title{
Emphysematous gastritis: a terrifying presentation
}

\author{
Ana Catarina Costa (ㄷ), Carlos Andre Barroso Oliveira 주, Manuela Certo
}

Radiology, Hospital de Braga, Braga, Portugal

\section{Correspondence to} Dr Ana Catarina Costa; anacatarinagcosta@gmail.com

Accepted 18 November 2020

\section{DESCRIPTION}

A 54-year-old woman with a known history of excessive alcohol ingestion (20 g/day) and depression was admitted at the emergency room with epigastric pain, haematemesis and melena.

At physical examination, she was found severally ill, with cold extremities and a distended abdomen. Hypotension $(80 / 50 \mathrm{~mm} \mathrm{Hg})$, tachycardia (160/ $\mathrm{min})$ and lower temperature $\left(34^{\circ} \mathrm{C}\right)$ were presented.

Blood tests showed anaemia (haemoglobin 101 $\mathrm{g} / \mathrm{l}, 119-156)$, leucocytosis $\left(15 \times 10^{9} / \mathrm{L} ; 4-11\right)$ with neutrophilia $76 \%$ and elevated levels of $\mathrm{C}$ reactive protein $(52.92 \mathrm{mg} / \mathrm{dL},<5)$, lactate dehydrogenase (LDH) (831 U/L, 120-246) and lactic acid $(8.6 \mathrm{mmol} / \mathrm{L}, 0.5-2)$. Aspartate aminotransferase (AST) was in the upper limit of normal range (53 U/L, 12-40). Acute renal lesion (pCr $1.9 \mathrm{mg} / \mathrm{dL})$ was also present.

A nasogastric tube was placed and a massive amount of blood and gas was drained off.

After the admission the patient initiated intravenous fluid resuscitation and broad spectrum intravenous antibiotherapy (ceftriaxone $2 \mathrm{~g}$ and metronidazole $1.5 \mathrm{~g}$ ).

Abdominal CT scan showed marked gastric distension and presence of mottle gas in the gastric wall, findings consistent with emphysematous gastritis. No portal venous gas was seen. A fish bone was also identified.

The axial (figure 1) and coronal (figure 2) views demonstrated marked stomach distention and the presence of intramural gas. Coronal view (figure 2) allowed us to see fish bone embedded in the gastric fundus. The absence of pneumoperitoneum excludes the existence of transmural perforation.

Other findings such as ascites, pleural effusion and stranding fat tissue were also found.

A life-saving total gastrectomy was performed with an oesophagus-jejunal anastomosis.

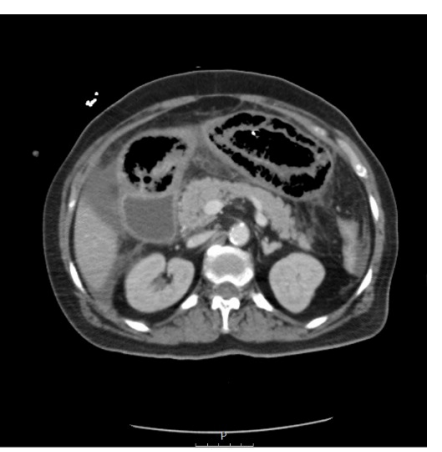

Figure 1 Emphysematous gastritis. Portal venous enhanced-CT scan (axial view) showed the mottle gas in the gastric wall. Ascites and mesentery fat stranding were also observed.

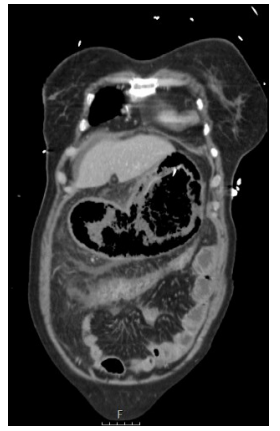

Figure 2 Emphysematous gastritis. Portal venous enhanced-CT scan (coronal view) exhibited the marked gastric distention with intramural gas. Note the fish bone embedded in the gastric fundus with no transmural perforation. No portal venous gas was seen.

Unfortunately, the patient died in the next week due to anastomosis dehiscence.

Later, in the blood culture an Escherichia coli was isolated.

Emphysematous gastritis is a rare entity with a high mortality rate. This pathology is classified as a subtype of phlegmonous gastritis, caused by gastric producing organisms. ${ }^{12}$

The gastric mucosa has a rich blood supply with a low $\mathrm{pH}$. These characteristics produce a resistant barrier to infection, explaining the existence of a trigger to disrupt the integrity. ${ }^{13}$

A correct and thorough investigation should always be made for other predisposing factors like corrosive substances (bases and acids), alcohol abuse, abdominal surgery, diabetes and nonsteroidal anti-inflammatory drugs (NSAID) abuse. The clinical presentation is usually ominous and fulminant with abdominal pain, nausea and vomiting as well

\section{Patient's perspective}

The family only said "It was very unexpected, we thought it was only something viral".

\section{Learning points}

- Emphysematous gastritis despites uncommon can have a fulminant and lethal presentation.

- Abdominal CT scan is important to diagnose the emphysematous gastritis by the presence of intramural gas and exclude potential aetiological agents.

- Nasogastric intubation can give a clue in diagnosis when necrotic tissue is present. 
shock. ${ }^{12}$ Our patient besides the abuse of alcohol and antidepressive drugs, also presents a foreign body.

Necrotic tissue in emesis or nasogastric aspirate is considered the main finding, resulting from the dissection of the muscularis mucosa. Definite diagnosis can be made by the presence of intramural gas with CT abdominal scan. Ultrasound is also very sensitive to detection of portal venous gas. ${ }^{23}$

Antibiotic covering gram negative organisms and anaerobes should always be tried, accompanied by surgery which may enhance survival. Intravenous fluids provide an essential part of the haemodynamic stabilisation. ${ }^{23}$

Contributors ACC reported the case and selected the images and reviewed the literature. She asked the patient family for consent to publish. CABO helped reporting the $\mathrm{CT}$ and image improvement and selection. He also helped planning. $M C$ supervised all the work and defined the plan to the study as well as analysis of the data.
Funding The authors have not declared a specific grant for this research from any funding agency in the public, commercial or not-for-profit sectors.

Competing interests None declared.

Patient consent for publication Next of kin consent obtained.

Provenance and peer review Not commissioned; externally peer reviewed.

\section{ORCID iDs}

Ana Catarina Costa http://orcid.org/0000-0002-1071-3608

Carlos Andre Barroso Oliveira http://orcid.org/0000-0002-7553-7422

\section{REFERENCES}

1 van Mook WNKA, van der Geest S, Goessens MLMJ, et al. Gas within the wall of the stomach due to emphysematous gastritis: case report and review. Eur J Gastroenterol Hepatol 2002;14:1155-60.

2 Matsushima K, Won EJ, Tangel MR, et al. Emphysematous gastritis and gastric emphysema: similar radiographic findings, distinct clinical entities. World I Surg 2015;39:1008-17.

3 Sen I, Samarasam I, Chandran S, et al. Gastric intramural and portal venous gas following blunt abdominal injury. Arch Trauma Res 2013;2:95-6.

Copyright 2020 BMJ Publishing Group. All rights reserved. For permission to reuse any of this content visit

https://www.bmj.com/company/products-services/rights-and-licensing/permissions/

BMJ Case Report Fellows may re-use this article for personal use and teaching without any further permission.

Become a Fellow of BMJ Case Reports today and you can:

- Submit as many cases as you like

- Enjoy fast sympathetic peer review and rapid publication of accepted articles

- Access all the published articles

Re-use any of the published material for personal use and teaching without further permission

Customer Service

If you have any further queries about your subscription, please contact our customer services team on +44 (0) 2071111105 or via email at support@bmj.com.

Visit casereports.bmj.com for more articles like this and to become a Fellow 